\title{
NOTES
}

\section{Protection of Nonimmune Volunteers against Rubella by Intravenous Administration of Normal Human Gamma Globulin}

\author{
R. Martin du Pan, B. Koechli, and A. Douath
}

From the Faculty of Medicine, University of Geneva, Geneva, Switzerland

\begin{abstract}
Standard gamma globulin, treated with pepsin and injected intravenously five days after infection, conferred passive protection against rubella on five volunteers. Intravenous injection of gamma globulin is superior to intramuscular injection, because the antibodies enter the bloodstream immediately, and an amount of antibody sufficient for protection can be given. Injection of standard gamma globulin is recommended when gamma globulin hyperimmune to rubella virus is unavailable.
\end{abstract}

Since the first description of rubella embryopathy by Gregg in 1942 [1], it has been proved beyond doubt that rubella infection during the first 16 weeks of pregnancy is a real danger for the embryo [2, 3].

Until every susceptible woman of child-bearing age can be protected against rubella by an effective and safe vaccine, passive protection of pregnant women who have come into contact with the disease will continue to be desirable.

The use of either standard or hyperimmune gamma globulin has been widely proposed since 1946, when Aycock and Ingalls [4] gave gamma globulin from normal human serum to four children infected with or exposed to rubella; however, reports of the efficacy of intramuscular injection of gamma globulin have been contradictory $[5,6]$. After it became possible to administer attenuated rubella virus intranasally to produce a benign disease, Schiff [7] showed that $20 \mathrm{ml}$ of highly titered immune globulin (titer of neutralizing antibody, $4,096 / 0.1 \mathrm{ml}$ ) administered $24 \mathrm{hr}$ after intranasal infection with attenuated rubella virus protected five nonimmune volunteers. In contrast, $20 \mathrm{ml}$ of normal gamma globulin administered in the same way failed to protect four out of six nonimmune young men.

Received for publication January 17,1972 , and in revised form June 8, 1972.

Please address requests for reprints to Dr. R. Martin du Pan, 22, Rue de Candolle, 1205 Geneva, Switzerland.
The poor results obtained by Schiff with im administration of normal gamma globulin could be explained by an experiment we did with gamma globulin labeled with ${ }^{131} \mathbf{I}[8,9]$. Three children (two to three years of age) and three adults were injected deeply in the gluteus muscle with $3-5 \mathrm{ml}$ of gamma globulin labeled with ${ }^{131} \mathrm{I}$. The injected gamma globulin remained at the site of injection for a rather long time, and only $5 \%-20 \%$ of the injected gamma globulin was found in the serum two to five days later. On the other hand, $40 \%$ of the gamma globulin labeled with ${ }^{131} \mathrm{I}$ and injected iv remained in the serum of one subject for a week.

We have already demonstrated that antibodies to rubella virus, administered iv as human plasma, persist with measurable titers for up to three weeks [10], as might be expected from established data on the half-life of homologous gamma globulin in man [11].

The risk of inducing serum hepatitis by injection of human plasma [12] led us to use iv injection of gamma globulin in our studies.

The preparation of hyperimmune gamma globulin for protection against rubella is very difficult, since it is not possible to boost levels of antibody by injection of live vaccine into persons already immune. Furthermore, it is not easy to find large numbers of persons who are convalescing from rubella and willing to give blood. Therefore, we decided to use standard gamma globulin, processed to be suitable for iv injection, to obtain 
a sufficiently high level of antibodies in the blood of the recipients to protect them against rubella.

\section{Experiments}

Gamma globulin. Intravenous gamma globulin has already been used on a large scale in Switzerland for treatment of patients with agammaglobulinemia or with serious bacterial infections [13, 14]. It is prepared by pepsin digestion of gamma globulin dissolved in a solution of glycine $(p \mathrm{H} 4.0)$ for $3 \mathrm{hr}$ at $37 \mathrm{C}$, followed by neutralization to $p \mathrm{H} 7.3[14,15]$. This method removes most of the anticomplementary properties of standard gamma globulin. The therapeutic effect in children suffering from agammaglobulinemia and in patients with bacterial infections and infections of the eyes with herpesvirus was generally good. Gamma globulin can be administered iv in large quantities without causing pain or serious reactions, and it is rapidly effective $[13,14]$.

The titers of HAI antibodies to rubella virus in five lots of normal gamma globulin prepared and furnished by the Blood Transfusion Laboratory of the Swiss Red Cross at Bern were 1,024 in four lots and 2,048 in one lot.

To study the protection against rubella conferred by iv gamma globulin, we determined the following: (1) the half-life of gamma globulin given iv, (2) the titer of HAI antibodies to rubella virus in the sera of nonimmune recipients of iv gamma globulin, (3) protection of nonimmune adults by iv injection of standard gamma globulin.

Half-life of gamma globulin injected iv. Two healthy, young adult volunteers were injected iv with $30 \mu \mathrm{Ci}$ of ${ }^{131} \mathrm{I}$-labeled gamma globulin after their thyroid glands were blocked with a $2 \%$ solution of KI. Blood samples were drawn at different time intervals during one week. After the presence of free ${ }^{131}$ I was ruled out, the biological half-life was determined; it was 7.1 days in the first person and 8.5 days in the second. These results are normal according to the literature [13].

Titer of rubella HAI antibodies in sera. Three nonimmune adults, two females ( $\mathrm{CB}$ and $\mathrm{FB}$ ) and one male, (JB) received iv infusions of 60,40 , and $60 \mathrm{ml}$, respectively, of normal gamma globulin diluted in $200 \mathrm{ml}$ of $0.9 \% \mathrm{NaCl}$.
Table 1. Titer of HAI antibodies to rubella virus in sera of recipients of $1 \mathrm{ml}$ of standard gamma globulin given iv.

\begin{tabular}{lccc}
\hline & \multicolumn{3}{c}{ Recipient } \\
\cline { 3 - 3 } Gamma globulin and blood & CB & JB & FB \\
\hline $\begin{array}{l}\text { Amount of gamma } \\
\quad \text { globulin injected }\end{array}$ & $60 \mathrm{mI}$ & $60 \mathrm{ml}$ & $40 \mathrm{ml}$ \\
$\begin{array}{l}\text { Titer of HAI antibodies/ } \\
\text { ml of gamma globulin }\end{array}$ & $1: 2,048$ & $1: 1,024$ & $1: 1,024$ \\
HAI antibodies in blood & & & \\
$\quad$ Before injection & 0 & 0 & 0 \\
$\quad$ After 5 min & $1: 64$ & $1: 32$ & $1: 8$ \\
After 1 day & $1: 16$ & $1: 16$ & $1: 8$ \\
After 5 days & $1: 16$ & $1: 8$ & $1: 8$ \\
After 14 days & $1: 8$ & $<1: 8$ & $<1: 8$ \\
\hline
\end{tabular}

Samples of blood were taken at intervals from 5 min to two weeks.

As can be seen from table 1, iv injection of 40 or $60 \mathrm{ml}$ of standard gamma globulin increased the level of antibodies in the sera of the recipients sufficiently to protect them against rubella. (It is generally accepted that an HAI antibody titer of $1: 8$ is protective.)

Protection of nonimmune adults by iv gamma globulin. To determine whether $30-60 \mathrm{ml}$ of standard gamma globulin (titer of rubella HAI antibodies, 1:1,000) given iv would protect against rubella, we chose seven students as volunteers who were assumed to be nonimmune on the basis of a negative history of rubella and absence of HAI antibody in serum.

All received $1 \mathrm{ml}$ of a solution containing $10^{4}$ TCID $_{50}$ viruses of the attenuated Brown strain intranasally. ${ }^{1}$ Five days later, five of the students received (iv) $30-60 \mathrm{ml}$ of gamma globulin diluted in $200 \mathrm{ml}$ of saline. Two students (NB and LT) remained as controls and were isolated.

Both controls developed mild rubella 10-14 days later; one had postauricular lymphadenopathy, slight rash and fever, arthralgia, and a rise in HAI antibodies to $1: 128$, while the other had the same symptoms, except for arthralgia. The titer of rubella HAI antibodies increased to 1:1,024 five weeks after inoculation of rubella virus in the second control subject.

\footnotetext{
1 Supplied by the National Institute of Allergy and Infectious Diseases, National Institutes of Health, Bethesda, Md.
} 
Table 2. Serologic evidence of protection against rubella with intravenous gamma globulin.

\begin{tabular}{|c|c|c|c|c|c|c|c|}
\hline \multirow[t]{3}{*}{$\begin{array}{l}\text { Subject } \\
(\operatorname{sex})\end{array}$} & \multirow[t]{3}{*}{$\begin{array}{c}\text { Weight } \\
(\mathrm{kg})\end{array}$} & \multirow[t]{3}{*}{$\begin{array}{c}\text { Dose of } \\
\text { gamma } \\
\text { globulin } \\
\text { (ml) }\end{array}$} & \multirow[t]{3}{*}{ Symptoms } & \multicolumn{4}{|c|}{ Titer of HAI antibodies } \\
\hline & & & & \multirow[b]{2}{*}{ Before } & \multirow[b]{2}{*}{$24 \mathrm{hr}$} & \multicolumn{2}{|c|}{ After } \\
\hline & & & & & & 3 weeks & 6 weeks \\
\hline NB (M) & 72 & 0 & + & 0 & 0 & $1: 256$ & $1: 1,024$ \\
\hline LT (F) & 62 & 0 & + & 0 & 0 & $1: 128$ & $1: 128$ \\
\hline FB (M) & 70 & 60 & - & 0 & $1: 6$ & 0 & 0 \\
\hline $\mathrm{MF}(\mathrm{M})$ & 75 & 40 & - & $\mathbf{0}$ & - & 0 & 0 \\
\hline $\mathrm{TB}(\mathrm{F})$ & 63 & 40 & - & 0 & $1: 8$ & 0 & 0 \\
\hline $\mathrm{AL}(\mathrm{F})$ & 68 & 30 & - & 0 & $1: 8$ & 0 & 0 \\
\hline RS (F) & 65 & 30 & - & 0 & $1: 8$ & 0 & 0 \\
\hline
\end{tabular}

Table 2 shows that none of the treated students had symptoms of rubella or elevated titers of antibodies. Three months later one of the students was infected by the Brown strain and showed symptoms of mild disease; he did exhibit a primary type of antibody response, another proof that he had been protected earlier by the gamma globulin. The titer of HAI antibody to rubella virus in his serum increased from $<1: 8$ before infection to $1: 128$ two weeks later and to $1: 1,024$ six weeks later.

\section{Discussion}

To protect a pregnant woman against rubella, we need to know when she was infected. Rubella virus may be cultured from pharyngeal secretions as early as one week before the onset of rash [5]. However, it is only two to three days before the onset of rash that the titer of excreted virus is really high [16]. A second factor to be considered is the number of days that elapse between infection and viremia. Viremia can be detected in the infected person as early as six days after infection $[5,17]$. Therefore, if we want to protect the fetus, we probably have only five days between infection and the iv administration of gamma globulin. The favorable results that we obtained support the theory that it should be possible to protect subjects if viremia is prevented.

In practical terms, if a pregnant woman is exposed to rubella, the first step is to determine whether or not she is immune [3, 17, 18] by testing her serum for antibodies. It is generally accepted that titer of HAI antibodies of $1: 8$ is enough for protection.
If she is not immune, $30-40 \mathrm{ml}$ of suitably treated, standard gamma globulin should be injected as soon as possible. The titer of HAI antibodies to rubella virus $10-25$ and 42 days later will show whether the subject has been protected from infection.

\section{References}

1. Gregg, N. M. Congenital cataract following German measles in the mother. Trans. Ophthalmol. Soc. Aust. 3:35-46, 1942.

2. Angela, G. C., Martinesco, G., Di Nola, F., Zunin, C., Vacca, C. La Rosolia. Minerva Med. 58: 4759-4826, 1967.

3. Martin, du Pan, R. Quels risques court une femme enceinte losque son enfant contacte une rubéole? Médecine et Hygiène 27:620-623, 1969.

4. Aycock, W. L., Ingalls, T. H. Maternal diseases as a principle in the epidemiology of congenital anomalies. Am. J. Med. Sci. 212:366-379, 1946.

5. Green, R. H., Balsama, M. R., Gilles, J. P., Krugman, S., Mitrick, G. S. Studies of the natural history and prevention of rubella. Am. J. Dis. Child. 110:348-365, 1965.

6. Brody, J. A., Sever, J. L., Schiff, G. M. Prevention of rubella by gamma globulin during an epidemic in Barrow, Alaska in 1964. N. Engl. J. Med. 272:127-129, 1965.

7. Schiff, G. M. The efficacy of titered lots of immune globulin in preventing rubella. International symposium on rubella vaccines. London 1968. Symposium series on immunobiological standardization, vol. 2, p. 83-94, 1969.

8. Martin du Pan, R., Scheidegger, J. J., Wenger, P., Koechli, B., Roux, J. J. Das Verhalten des intramuscular, intravenos und per os verabreichten gamma globulin. Blut 5:104-114, 1959.

9. Martin du Pan, R., Wenger, P., Koechli, B., Scheidegger, J. J., Roux, J. Etude du passage de la 
gamma globuline marquée à travers le placenta humain. Clin. Chim. Acta 4:110-115, 1959.

10. Martin du Pan, $\mathbf{R}$. Protection of pregnant woman against rubella. Lancet 2:546, 1969.

11. Wiener, A. S., Gordon, E. B. Studies on human serum gamma globulin: I. Half-life and rate of protection. J. Lab. Clin. Med. 49:258-262, 1957.

12. Cockburn, W. C., Harrington, J. A., Zeitlin, R. A., Morris D., Camps, F. E. Homologous serum hepatitis and measles prophylaxis. Br. Med. J. 2:6-8, 1951 .

13. Barandun, S. Die gamma-globulin therapie. Bibl. haematol. 17(Suppl.):7-134, 1964.

14. Barandun, S., Riva, G., Spengler, G. Immunologic deficiency diagnosis forms and current treatment.
Birth defect: Origin. Series National Foundation p. $40-46,1970$.

15. Kistler, P., Zahler, P. Probleme bei der Herstellung intravenos verabreichbarer humaner Gamma Globulin Lösungen, Pathol. Microbiol. 27:564$571,1964$.

16. Cooper, L. Z., Krugman, S. Clinical manifestations of postnatal and congenital rubella. Arch. Ophthalmol. 77:434-439, 1967.

17. Schiff, G. M., Sever, J. L. Rubella: recent laboratory and clinical advances. Progr. Med. Virol. 8:30-61, 1966.

18. Krugman, S., Ward, R. Demonstration of neutralizing antibody in gamma globulin and reevaluation of the rubella problem. N. Engl. J. Med. 259: 16-19, 1958. 